\title{
PIOTR KROPOTKIN: BREVE INTRODUÇÃO AO AUTOR
}

\section{Rodolpho Jordano Netto}

Piotr Kropotkin, pensador e ativista de peso no que se convencionou chamar de "Anarquismo Clássico", nasceu em 1842 em Moscou, Rússia, como príncipe da família real de Rurik. Na transição da fase adolescente para a adulta, serviu ao exército, que trouxe uma guinada importante para sua vida. No serviço militar Kropotkin teve contato com a militância e literatura revolucionárias, como os livros do anarquista Pierre J. Proudhon. Após esse contato, já adulto, rejeitou seu título de nobreza, dedicando-se à militância anarquista até sua morte em 1921.

Em 1867, ao voltar do serviço militar, ingressou na Universidade, onde apresentou diversos trabalhos sobre suas expedições à região siberiana de Vitim. Logo após foi nomeado secretário da seção de Geografia Física da Sociedade Geográfica Russa. Neste mesmo período (1871-1873) explorou as regiões glaciais da Finlândia e da Suécia. Além disso, realizou diversos trabalhos sobre a estrutura orográfica da Ásia.

Seus trabalhos em Geografia não se limitaram apenas à Geografia Física, tendo escrito diversos trabalhos sobre educação em Geografia', entre diversas outras temáticas. Para Maximiliano Astroza-León ${ }^{2}$, o livro Fields, Factories and Workshops, de onde retiramos o capítulo aqui traduzido, é um dos mais importantes trabalhos de Kropotkin sobre geoeconomia. Segundo o autor "A geoeconomia de raiz kropotkiniana constitui uma base crítica à configuração espacial das atividades humanas advindas da economia capitalista e da atuação do Estado como produtores de desigualdades, hierarquias e dependências econômicas regionais"3.

Além de "Fields, Factories and Workshops", suas principais obras são "The conquest of bread" ["A conquista do pão"] (1892), onde aponta os efeitos degradantes do sistema econômico feudal e do capitalismo que se sustentam através da pobreza e miséria de muitos, e "Mutual Aid: A Factor of Evolution" ["Mutualismo: um fator de evolução"](1902), aonde questiona as teorias de Darwin e dos darwinistas sobre a competição entre as espécies como fator de evolução. Nesse livro, discorre sobre o que chama de "mutualismo", a ajuda mútua entre espécies, que observou através de suas diversas expedições geográficas.

Apesar de sua vasta obra o autor ainda se mantém pouco estudado na história do pensamento geográfico. 0 texto que trazemos aqui se refere a trechos do primeiro capítulo de "Fields, Factories and Workshops", onde Kropotkin discorre sobre a divisão do trabalho e a importância da descentralização da indústria e da autosuficiência de cada Estado-nação. Optamos por publicar apenas a discussão mais ampla, de ordem teórica, ressaltando entretanto que há uma longa parte do texto em que o autor analisa realidades concretas como as da Inglaterra, França, Rússia e Estados Unidos. 